УДК 81'276.6

DOI: $10.26435 /$ UC.V0I4(37).622

\title{
S.Y. Taneva
}

Medical University, Sofia, Bulgaria

\section{MEDICAL DISCOVERIES, DISEASES AND SYNDROMES IN EPONYMOUS TERMINOLOGY (BASED ON ENGLISH, RUSSIAN AND BULGARIAN MEDICAL DISCOURSE)}

There are characteristics, qualities of linguistic unit (word or phrase) in scientific text on the basis of which it can be identified as a scientific term. They are perceived as requirements which, despite being idealized to a certain extent, outline general terminological norm and find concrete manifestations in actual terminological norms of each scientific or technical field. Therefore, such characteristics are defined as scientific term parameters (fig.).

1. Unambiguity - In all definitions of scientific term the association of terms with scientific concepts is emphasized. An obligatory requirement for this connection is that it should be unambiguous - each term is supposed to mean one scientific concept and each scientific concept needs to be expressed within one term. In medical terminology, the problem of unambiguity is solved by means of Latin nomenclature, which provides a unique name in Latin for each medical organ, disease, syndrome, symptom, technology, instrumentarium, etc.

2. Accuracy - This parameter refers to the relationship between the term name and terminological meaning. The term name should reflect the essence of concept as accurately and completely as possible and, simultaneously, define it most clearly. Hence it is advisable construction of the term name to be logical.

3. Brevity - Term needs to be short but this requirement cannot be followed consistently. In today's medical terminology, the term word combinations constitute a large proportion as there are very long terminological units. Thus the essence of the concept is expressed more completely.

4. Systematicity - Term systematicity means the selection of such a form that puts it in a certain relation to the other terms in the respective terminological subsystem. This is a requirement for the linguistic form to express classification conceptual features.

5. Grammatical correctness - Terms adopt the norms for phonetic and grammatical correctness of the relevant literary language. In association with this parameter it is important to specify which morphological and syntactic structures in the terminological word combinations are subject or not subject to standardization.

6. Stylistic neutrality - Terms are not carriers of expression but only name concepts without introducing additional stylistic nuance. Therefore, as a rule, they do not have connotative meanings.

7. Word formation - Term should have the capacity to form derivative words - from the basis of a term to form another one.

\section{PURPOSE AND OBJECTIVES OF THE STUDY}

In addition to the aforementioned parameters, scientific term is a unit of specialized communicative act. This necessitates the following objectives we have set ourselves in the current research:

1 . To consider medical terminology on a pragmatic level.

2. To outline multidimensionality of medical domain.

3. To determine the specificity of medical eponymous term.

4. To make a general characteristic of the selected eponymous terms in the medical discourse of English, Russian and Bulgarian academic languages in terms of terminological semantics.

5. To direct the present research a) to foreign language terminological training at medical universities; b) to giving lectures and conducting seminars on general linguistics and applied terminology issues; c) to expanding the linguistic medical competence of medical students and professionals.

\section{MATERIALS AND METHODS}

The objectives of the study led to the inclusion of English, Russian and Bulgarian medical eponymous terminology in the field of science, mythology and li-

(C) S.Y. Taneva, 2020

(c) Университетская Клиника, 2020 


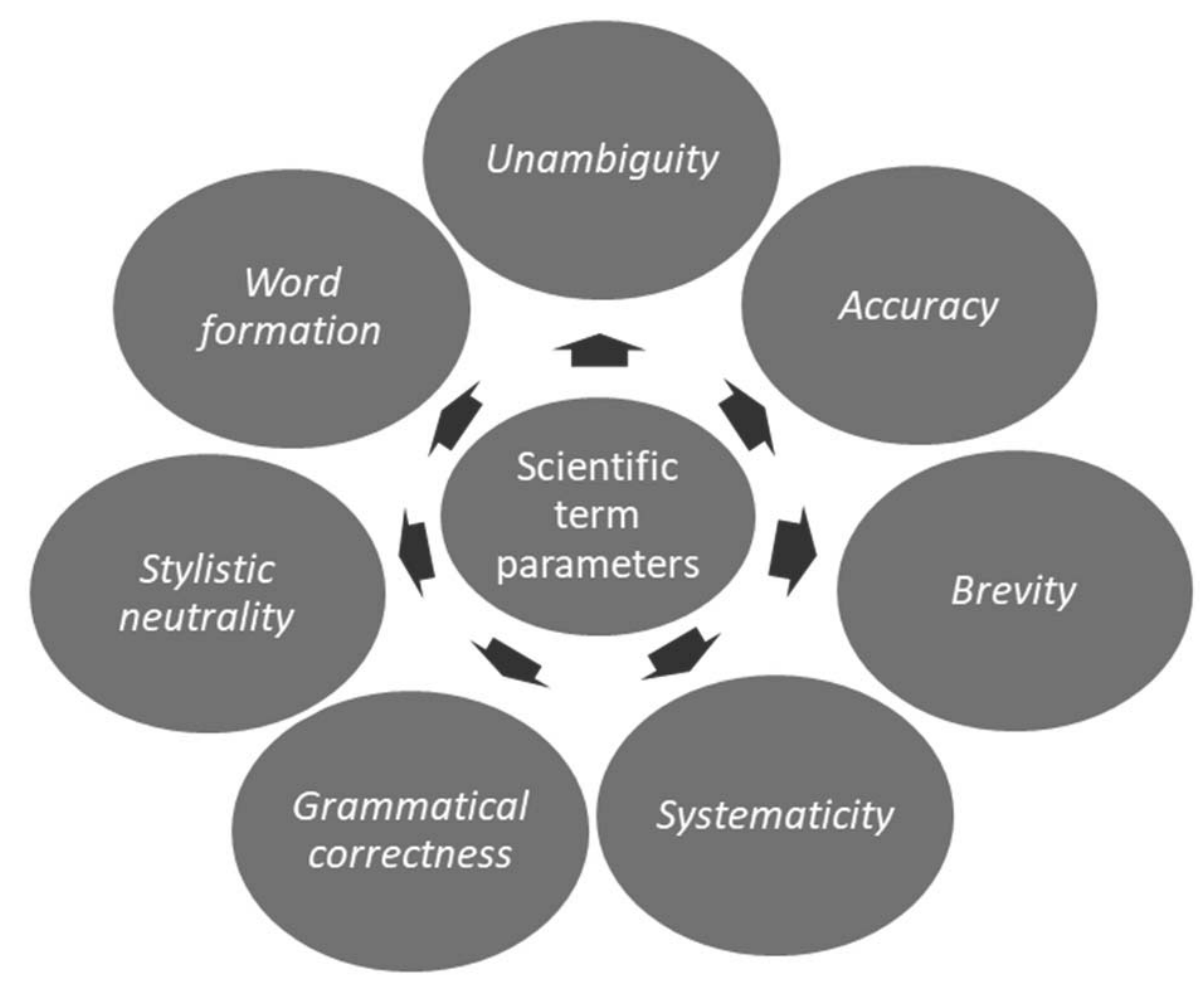

Fig. Scientific term parameters

terature. The terminological units have been collected at random from monographs, articles, textbooks, terminological dictionaries, encyclopedias, reference books, Internet catalogues, etc. Thirty (30) compound eponymous terms (including all translation equivalents in the three languages) have been discussed.

The realization of the present research is due to the application of the following methodology:

1. Method of definition analysis;

2. Method of conceptual integration;

3. Method of cognitive analysis;

4. Method of eponymous modelling; 5. Etymological method of analysis.

\section{RESULTS AND DISCUSSION}

On a pragmatic level, medical terminology studies the ability of participants in the communicative act to exchange information successfully at a higher level. In this regard, various studies have been done in specialized language, namely, on interactions between different groups of users in a given specialized context $[8,11]$; outlining the parameters of the specialized contexts for modelling [6, 7]; specialized text analyzes $[4,9]$; terminological variability $[2,5]$.

In specialized medical communication, pragmatic dimensions include: sender's view of life and expectations; knowledge shared by the participants in times of communicative act; communica- tive purposes of both oral and written texts; factors that make the recipient interpret the text in a certain way; facts about social and academic institutions where events generate specialized texts (for instance, a conference on nanotechnology in medicine where the results are presented within the particular field of knowledge).

Hence is the didactic aspect of the present study. Medical terminology, respectively the eponymous terms (which are the subject of current study), is a must in the teaching of biomedical disciplines in order to conceptualize medical knowledge, as the term name focuses on the meaning of the real anatomical object or medical condition and is the first starting point for understanding its essence. The discussion and clarification of the origin, structure and meaning of medical terms and terminological elements is an important component in learning process at medical universities that allows to comprehend medical information with the aid of native language (for students being taught in their native country) and the working academic language (for foreign students).

In particular, at Medical University - Sofia, Bulgaria, the training process in medical terminology is conducted in Bulgarian, English, Russian, German and French depending on the faculty, level and duration of the terminological language course. Most of the training is mandatory. Optional terminology language courses are available, as well. Such 
courses provide the appropriate number of credits for each student. The importance of English, Russian and Bulgarian for medical education in Bulgaria determined our language choice for the present research.

In addition, the idea that the medicine domain can be projected simultaneously on many other domains is the basis for the concept of multidimensionality of specialized medical lexis $[1,3,10]$. Domains where medical terminology has already been introduced are, as follows: ecology, economics, politics, computer technology, automotive engineering, etc. In computer technology, the patient is the computer, the disease is a virus and the computer specialist is in his capacity as a doctor who is expected to determine the type of virus (diagnose it) and to determine the way for its removal (carry out treatment until complete recovery). In politics, such a statement - "The coronavirus has unleashed one of the biggest plagues in today's society" shows how the medical frame "plague" reaches the domain of politics.

Furthermore, medical terminology, by means of the eponymous terms, freely enters the fields of names of great scientists - discoverers, mythological and literary characters. "Eponym" comes from Greek word "eponymos" ("epi" - upon + "onima" name) and means "giving his name". The demand for the presence of eponymous terms in medicine is determined by the denotative function they perform. They name pathological conditions - diseases and syndromes - for which science does not have a name yet. However, eponyms vary in different languages and due to their mnemonic nature, complicate the process of learning medical terminology. Therefore, they are often replaced by descriptive terms. The encyclopedic informational volume of the eponymous terms and expressiveness is what makes them so unique.

\section{The greatest minds of science eponyms}

In the present study we will consider two eponyms in English, Russian and Bulgarian academic languages, named after scientists and doctors who immortalize their names by means of the discoveries they make. For some of them, science is a relatively short episode at the beginning of their professional careers, while others dedicate their entire lives to fundamental science, winning the Nobel Prize.

1. Call-Exner bodies/mельца Колла-Экснера/ телца на Кол-Екснер - Call-Exner bodies is the eponymous term name given to small follicular structures seen in granulosa cell tumours (GCTs), as they resemble the immature follicles first described by Call and Exner in the ovaries of rabbits in 1875 . GCTs are rare sex cord stromal tumours of the ovary often secreting oestrogen and appearing as rosettes of granulosa cells surrounding an eosinophilic material. Call-Exner bodies are the hallmark of GCTs, occurring in $30-60 \%$ of cases. They are small follicle-like structures that punctuate the sheet-like arrangement of the tumour cells. Call-Exner bodies can be detected by immuno-histological staining with inhibin and fine-needle aspiration cytology.

The considered pathological entity is named after Emma Call - one of the first woman doctors in the USA and the first one elected as a member of the Massachusetts Medical Society. She worked in the field of obstetrics for 40 years. The great physician described Call-Exner bodies in collaboration with Sigmund Exner, Austrian physiologist and psychologist and her mentor. Sigmund Exner is remembered for his important contributions to comparative physiology and brain research. In addition to Call-Exner bodies, other medical eponyms such as Exner's nerve, Exner's plexus and Exner's area (an area within the brain allowing for writing function) are linked to his name.

2. Curie unit of radioactivity/единица измерения радиоактивности кюри/единица за радиоактивност кюри - Curie (Ci) is an extrasystem unit for radioactivity. It is defined as $1 \mathrm{Ci}=3.7 \times 1010 \mathrm{de}$ cays per second. This eponymous term immortalizes the name and incredible story of the "radioactive" woman - scientist Marie Curie. Marie and Pierre Curie (her husband) were completely devoted to each other and science. Initially they worked on separate projects but Pierre frequently assisted Marie. Soon she was intrigued by Henry Baccarel's discovery, a French physicist, who found that uranium emits rays different from the X-rays that Wilhelm Röntgen discovered. Curie began conducting her own experiments with uranium and found that the rays it emitted were constant regardless of the condition and shape of uranium. She published a theory asserting that the rays came from the atomic structure, naming the revolutionary idea of radioactivity and thus, giving rise to a new field in physics. Marie Curie became the first scientist to receive two Nobel Prizes in physics and chemistry - in physics (1903), together with her husband and Baccarel for their work on radioactivity, and in chemistry (1911) for her discovery of radium and plutonium. Marie Curie is also the first woman professor in the history of Sorbonne.

\section{The mythology eponyms}

The two mythological eponyms identified in the current study provide the complex realities of neurological disorder and chronic venous disease with a mythological dimension.

1. Syringomyelia/сирингомиелия/сирингомиелия - It is a rare progressive neurological disorder characterized by the formation of cavities in the spinal cord. The disorder is named after Syrinx (a 
nymph) that was in love with Pan (a satyr). Running away from him, Syrinx reached a river bank, begged the water gods to save her, giving her another image. When Pan tried to reach her, he embraced the swamp reeds into which Syrinx had been turned. Then he made a multi-barrel flute from the hollow reed stems and named it after his beloved - the nymph Syrinx. Presently this musical instrument is known as pan flute.

Syringoma is a rare benign tumor most often localized in the eyelid area, originating from the tubules of sweat glands, characterized microscopically by their cavity-tubular structure. Along with motor disorders, there is a disorder of sweating - a decrease or absence of sweat.

2. Caput Medusae/голова медузы/главата на медуза - This eponymous term is named after Medusa - one of the three monstrous Gorgons, depicted as winged females with living snakes instead of hair. After a love affair with Poseidon, Medusa was punished by Athens turning her hair into snakes. Caput Medusae is varicose dilated paraumbilical veins in portal hypertension. The main symptom is a network of enlarged, visible, painless, wrinkled subcutaneous veins around the abdomen. From a distance, it might look like a black or blue bruise. It is often a sign of an underlying condition, usually liver disease. Nowadays Caput Medusa is rare due to improved methods for diagnosing liver disease in its earlier stages.

\section{The literary eponyms}

In the field of literature two eponymous terms in English/Russian/Bulgarian medical discourse have been selected reflecting psychiatric syndromes.

1. Rapunzel syndrome/ Синдром Рапунцель/ синдром на Рапунцел - Golden-haired Rapunzel from the fairy tale of the Brothers Grimm, imprisoned in an impregnable tower by the fault of an evil sorceress, once dropped her thick long hair through the window so that the prince could climb up, like a ladder, and save his beloved.

Named after the fairytale heroine, Rapunzel syndrome is an extremely rare condition. $\mathrm{Pa}-$ tients usually experience an uncontrollable desire to pluck hair (trichotillomania/ трихотилломания/ трихотиломания) and ingest it (trichophagia/ трихофагия/ трихофагия). As a result, a large amount of tangled hair accumulated in the stomach leading to the formation of trichobezoar/ трихобезоар/mрихобезоар (a foreign body composed of hair or hair tumor). In shape, such a tumor resembles a ball with a long tail. The rare cases in which trichobezoar continues in small intestine (similar to a rope) are known among surgical community as Rapunzel syndrome. Traditionally it is believed that women are much more susceptible to Rapunzel syndrome than men. People with intellectual disabilities or some types of mental disorders are generally at increased risk of developing such a syndrome. In most cases, surgery remains the most effective method for removing the hair tumor. In addition, hair formation can also be dissolved upon the influence of chemicals or broken up into small components using a laser.

2. Cinderella syndrome/ синдром Золушки/ синдром на Пепеляшка - Inversely proportional to the fame of another fairy-tale heroine - Cinderella - is that of the eponymous psychiatric syndrome. In fact it is a fairy-tale disease with non-fabulous consequences. Such medical condition describes a personality disorder characterized by a fear of independence and an unconscious desire for someone else to take care of you. Those suffering from Cinderella syndrome remain forever waiting for the prince to solve their problems.

Adopted children and those from different marriages most frequently suffer from this disease and make up scary stories about how they were abused by their stepmothers or stepfathers. Some psychologists suggest that in many cases there is a discriminatory attitude towards such children and this may be due to the lack of connection between motherfather and children. Cinderella syndrome is also associated with females who have developed complexes that make them emotionally dependent on males. They simply need a man by their side. No matter how successful they are in their career and life, they do not feel complete without a partner. Such women tend to be anxious, insecure and with low self-esteem.

\section{CONCLUSIONS}

1. Availability of an expanded medical eponymous terminological fund in science, mythology and literature has been indicated.

2. Applied and didactic aspects of medical eponymous lexis have been proved. Medical eponymous term has a high encyclopedic informative value for both students and professionals.

3. Scientific term parameters are, as follows: a) Unambiguity; b) Accuracy; c) Brevity; d) Systematicity; e) Grammatical correctness; f) Stylistic neutrality; g) Word formation.

4. Medical terminology "invades" a number of areas: politics, ecology, computer technology, economics, literature, mythology, etc. This determines its multidimensionality. 


\section{С.Й. Танева}

Медицинский Университет, София, Болгария

\section{МЕДИЦИНСКИЕ ОТКРЫТИЯ, ЗАБОЛЕВАНИЯ И СИНДРОМЫ В ЭПОНИМНОЙ ТЕРМИНОЛОГИИ (НА ОСНОВЕ АНГЛИЙСКОГО, РУССКОГО И БОЛГАРСКОГО МЕДИЦИНСКОГО ДИСКУРСА)}

В данном исследовании обсуждаются тридцать эпонимных медицинских терминологических единиц, названных в честь великих ученых, врачей, мифологических и литературных персонажей. Эпонимные термины представлены в английском, русском и болгарском медицинском дискурсе. Сделаны краткие медицинские описания конкретного открытия, заболевания или синдрома. Дается информация о личности, в честь которого назван эпонимный термин. Выявлены основные параметры научного термина: а) Однозначность; б) Точность; в) Краткость; г) Системность; д) Грамматическая правильность; е) Стилистический нейтралитет; ж) Словообразование. Особое внимание уделяется специфике медицинского эпонимного термина, его энциклопедической информативности и дидактическому аспекту в процессе преподавания специализированной медицинской лексики в медицинских университетах. Выделяется „инвазивность“ медицинского домэйна в ряде других областей: политика, компьютерные технологии, экономика, автомобильное инженерное дело, экология и т.д. (на основе конкретных примеров).

Ключевые слова: английский / русский / болгарский эпонимный термин, медицинская эпонимная терминология, открытие, заболевание, синдром.

\section{S.Y. Taneva}

Medical University, Sofia, Bulgaria

\section{MEDICAL DISCOVERIES, DISEASES AND SYNDROMES IN EPONYMOUS TERMINOLOGY (BASED ON ENGLISH, RUS-SIAN AND BULGARIAN MEDICAL DISCOURSE)}

Thirty medical eponymous terminological units named after great scientists, physicians, mythological and literary characters have been debated in the current study. The eponymous terms are presented in English, Russian and Bulgarian medical discourse. Brief medical descriptions of the particular discovery, disease or syndrome have been made. Information is given about the person after whom the eponymous term is named, as well. The basic parameters of scientific term are identified: a) Unambiguity; b) Accuracy; c) Brevity; d) Systematicity; e) Grammatical correctness; f) Stylistic neutral- ity; g) Word formation. Special attention is paid to the specifics of medical eponymous term, its encyclopedic informative volume and didactic aspect regarding the teaching process of specialized medical vocabulary at medical universities. Medical domain "invasion" is highlighted in a number of other domains: politics, computer technology, economics, automotive engineering, ecology, etc. (based on specific examples).

Key words: English/Russian/Bulgarian eponymous term, medical eponymous terminology, discovery, disease, syndrome.

\section{REFERENCES}

1. Bowker, L. Multidimensional classification of concepts and terms. In S. E. Wright and G. Budin (eds.). Handbook of Terminology Management. Philadelphia/Amsterdam: John Benjamins. 1997; 131-143.

2. Bowker, L. \& Hawkins, S. Variation in the organization of medical terms. Exploring some motivations for term choice. Terminology. 2006; 12 (1): 79-110.

3. Bowker, L. \& Meyer, I. Beyond 'textbook' concept systems: handling multidimensionality in a new generation of term banks. In K.D. Schmitz (ed.), TKE'93: Terminology and Knowledge Engineering, Frankfurt: Indeks. 1993; 123-137.

4. Darian, S. The language of classifying in introductory science texts. Journal of Pragmatics. 1997; 27: 815-839.

5. Freixa, J. Causes of denominative variation in terminology: A typology proposal. Terminology. 2006; 12 (1): 51-77.

6. Gero, J. S. \& Smith, G. J. Context and design agents. In B. Kokinov, D. C. Richardson, T. R. Roth-Berghofer and L.
Vieu (eds). Modeling and Using Context. Berlin/Heidelberg: Springer. 2007; 220-233.

7. Kerremans, K.et al. Application oriented terminography in financial forensics. Terminology. 2005; 11 (1): 83-106.

8. Lehtinen, E. Merging doctor and client knowledge: On doctors' ways of dealing with clients' potentially discrepant information in genetic counseling. Journal of Pragmatics. 2007; 39: 389-427.

9. Meyer, I., Bowker, L. \& Eck, K. COGNITERM: An experiment in building a knowledge-based term bank. In Proceedings of Euralex '92. Tampere: Finland. 1992; 159-172.

10. Meyer, I. \& Mackintosh, K. Refining the terminographer's concept analysis methods: how can phraseology help? Terminology. 1996; 3 (1): 1-26.

11. Vickers, C.H. Language competence and the construction of expert-novice in NS-NNS interaction. Journal of Pragmatics. 2009; 42 (1): 116-138. 